\title{
A review of blockchain and cryptocurrency applications in Romania
}

\author{
Maria NIȚU \\ Bucharest University of Economic Studies, Bucharest, Romania \\ maria.nitu@rei.ase.ro \\ Cristian NEGRUȚIU \\ Bucharest University of Economic Studies, Bucharest, Romania \\ cristian_negrutiu@yahoo.com
}

\begin{abstract}
Recent technological developments have led to economic changes that have an impact on the macroeconomic and microeconomic levels in developing countries, as well as in developed ones. The introduction of cryptocurrencies (Bitcoin is the first cryptocurrency, made public in 2009) into the economy through blockchain technology, generated a series of benefits, but also significant risks for citizens, companies and states.

The main purpose of this article is to present the operating mechanism of the blockchain system and cryptocurrencies, their advantages and disadvantages and the attempts of the international authorities to regulate the crypto market. The authors will present also few case studies of tech start-ups that leveraged the versatility of blockchain principles into viable business propositions. Romania makes no exception in this field, so the authors will analyze and present the current status of this industry.
\end{abstract}

Keywords: Blockchain, Cryptocurrencies, Bitcoin, Romania, Tech Start-ups.

\section{Introduction}

The technological evolutions that have taken place in the last 20 years have allowed the realization and issuance of virtual money, as an alternative to the traditional financial system, which with the crisis of 2008 generated a lot of mistrust and concern from the population. Citizens' reluctance regarding banking services has led to a reevaluation and the possibility of adopting a virtual currency, independently, with lower transaction costs.

At the same time, internet access has encouraged the widespread use of the blockchain system and cryptocurrencies. Thus, the virtual currency, Bitcoin, put into circulation in 2009 represented a financial revolution. Blockchain technology has been rapidly adopted in applications in various industries, creating platforms designed to store, transmit and manage digital information. The nature and volatility of cryptocurrencies lead to an increase in their popularity and especially in their use.

The authorities noticed the dimensions of this process and the speed with which cryptocurrencies developed, so that the main objective was to ensure their balance and regulation, by issuing laws applied collectively, nationally and internationally. At the same time, the anonymity that governs cryptocurrencies is a concerning matter for authorities, banks and states, as it causes mistrust regarding the people involved, where these cryptocurrencies come from, as well as their aim. Widespread adoption by users has led regulators to take action and create an efficient legislative framework to protect stakeholders. The development of regulations is an ongoing process in which some countries are open to the opportunities offered by cryptocurrencies, while others are categorically opposed to this process. In Romania, although there is reluctance 
among the authorities, the blockchain and cryptocurrency sector is in full expansion, and technological start-ups are thriving from this reality.

This article aims to review the advantages and disadvantages of cryptocurrencies and the authorities' attempts to react and regulate this technological innovation that will benefit users and investors and avoid generating negative effects such as terrorist financing, money laundering, tax evasion, etc., as well as a study focused on main tech start-ups active in this sector in Romania, performing a market survey based on available public sources.

\section{Literature review}

Created in 2008 as an alternative payment mechanism, Bitcoin was developed by Satoshi Nakamoto (Nakato, 2008) and was put into circulation in 2009, revolutionizing the existing financial system. Thus, Bitcoin represents a technological innovation through which transactions are peer-to-peer - without the involvement of third parties, decentralized, low cost and anonymous, which protects the privacy of the user. Cryptocurrencies (alternatives to fiat money) represent a virtual currency through which consumers can make various digital payments for the purchase of services or goods, without resorting to intermediaries (Edward et al., 2015). At the same time, the parties involved (seller and buyer) come into direct contact with each other (peer-to-peer), but their identity is anonymous and their personal data are not transferred between them (Edward et al., 2015).

Cryptocurrencies operate in an immaterialized system, which holds structural records of the network according to the Big Data characteristics of the $5 \mathrm{~V}$ - quality, volume, value, truthfulness and speed (Hossein et al., 2018; Samuel et al., 2015).

According to The Financial Action Task Force, The European Banking Authority and the International Monetary Fund cryptocurrencies are virtual currencies (FATF) and The World Bank has classified them as digital currencies (European Parliament, 2018).

Bitcoin, is the most recognized cryptocurrency internationally, becoming even an emblem of digital currencies (Mourdoukoutas, 2018). Cryptocurrencies, as well as their impact, are closely related to Blockchain technology.

The Blockchain system is an innovation, causing disruption to the level of established and traditional business actions, because applications or transactions can be performed in a decentralized manner with certainty. Blockchain is a data structure that is reproduced and distributed within the network, between participants. Blockchain or Distributed Ledger Technology (DLT) works for both Bitcoin and other virtual currencies, alternatives to bitcoinaltcoins (Scheau, Zaharie, 2018), through this technology that is based on an infrastructure and registries. The nodes of the network called miners, connect, in chronological order, the blocks that contain the hash of the previous one in order to create the blockchain (Crosby et al., 2016; Fran et al., 2018), keeping all transactions performed in a register.

Thus, based on computer systems (located in separate places) transactions are confirmed and also updated and synchronized various records in a network, through this technology based on an infrastructure and registers (Scheau, Zaharie, 2018).

Thus, blockchain technology is similar to "a distributed registry based on cryptography" (Taylor et al., 2020, p. 147) which allows various transactions between participants who are not confident in the network. The applicability of blockchain technology can be observed in various fields of activity, such as: Internet of Things, medicine, software engineering, medicine (Xiaoqi et al., 2017), logistics, banking, etc. 
The scale of this system and the popularity of its spread have demonstrated its lasting impact, its unique features and its security features have made it a subject of great interest, subject of many scientific studies (Taylor et al., 2020, p. 147).

The architecture of the blockchain system has a number of features, such as: security, robustness, transparency and audibility (Christidis and Devetsikiotis, 2016; Fran et al., 2018) which can generate both advantages and disadvantages.

Different countries or geographical areas have other names for other cryptocurrencies, such as: cyber currency- Italy, Lebanon, virtual commodity- Canada, Taiwan, China, digital currencyAustralia, Thailand, Argentina, payment token- Switzerland, virtual asset- Mexico, Honduras, crypto-token- Germany, electronic currency- Lebanon, Colombia (The Law Library of Congress, 2018, p. 1)

The main disadvantages or dangers that underlie cryptocurrencies, respectively Bitcoin are:

- Transactions made with Bitcoin cannot be tracked, which can generate or favor illegal money laundering, illicit trade in drugs, drugs or terrorist financing, and anonymity is a solid argument to challenge these cryptocurrencies, because it involves security risks. and operational as a result of speculative cyber attacks;

- Low confidence and reluctance of financial markets regarding the possibility of adopting these currencies (Bech, Garratt, 2017) due to the lack of an institution authorized to govern this currency (Scheau, 2018), but also of traders;

- Lack of guarantee on the value of Bitcoin;

- The existence of a limited number of coins that can be made and issued by the system;

- Internet addiction (Dumitrescu, An X-ray of the Bitcoin cryptocurrency);

- Increased risk due to high volatility and facilitation by organizations of unregulated transactions (The Law Library of Congress, 2018);

- Vulnerability, because virtual currencies can be subjected to hacker attacks, phishing (Schroeder, 2017);

- High energy consumption;

- Fluctuation of the value of the cryptocurrency as a result of a limited number of transactions;

- (Richter, Sascha Kraus, Bouncken, 2015);

- Prohibition of the use of virtual currencies by regulators.

Regarding the benefits, we encountered as follows:

- Exclusion of financial intermediaries / third parties from digital payment operations;

- Possibility to make quickly, regardless of time or place, payments or to receive money, Low risk of fraud, unlike classic payment systems;

- They cannot be counterfeited, there are a limited number of virtual coins (21 million) (Dwyer, 2015);

- Transaction costs are low;

- Technological innovation that can represent a successful investment;

- Lack of inflation and the transparency in the process of conducting operations (Richter, Sascha Kraus, Bouncken, 2015).

According to Table. 1, Regulation of Cryptocurrency Around the World, worldwide there are various measures to regulate, ban or issue cryptocurrencies. 
Tabel 1. Regulation of Cryptocurrency Around the World

\begin{tabular}{|c|c|c|c|c|c|}
\hline \multicolumn{2}{|c|}{$\begin{array}{c}\text { Legal Status } \\
\text { of Cryptocurrencies }\end{array}$} & \multicolumn{3}{|c|}{$\begin{array}{l}\text { Regulatory Framework } \\
\text { for Cryptocurrencies }\end{array}$} & \multirow{2}{*}{$\begin{array}{c}\text { Countries that } \\
\text { Have or Are } \\
\text { Issuing National } \\
\text { or Regional } \\
\text { Cryptocurrencies } \\
\\
\\
\text { Countries that } \\
\text { Have or Are } \\
\text { Issuing National } \\
\text { or Regional } \\
\text { Cryptocurrencies }\end{array}$} \\
\hline Ban & Implicit ban & $\begin{array}{l}\text { Application } \\
\text { of Tax Laws }\end{array}$ & $\begin{array}{l}\text { Anti-Money } \\
\text { Laundering } \\
\qquad \& \\
\text { Anti-Terrorism } \\
\text { Financing Laws }\end{array}$ & $\begin{array}{c}\text { Application } \\
\text { of Tax Laws } \\
\& \\
\text { Anti-Money } \\
\text { Laundering } \\
\text { \& Anti- } \\
\text { Terrorism } \\
\text { Financing } \\
\text { Laws } \\
\end{array}$ & \\
\hline Algeria & Bahrain & Argentina & Cayman Islands & Australia & Anguilla \\
\hline Bolivia & Bangladesh & Austria & Costa Rica & Canada & $\begin{array}{l}\text { Antigua and } \\
\text { Barbuda }\end{array}$ \\
\hline Egypt & China & Bulgaria & Czech Republic & Denmark & China \\
\hline Iraq & Colombia & Finland & Estonia & Japan & Dominica \\
\hline Morocco & $\begin{array}{l}\text { Dominican } \\
\text { Republic }\end{array}$ & Iceland & Gibraltar & Switzerland & Ireland \\
\hline Nepal & Indonesia & Israel & Hong Kong & & Lithuania \\
\hline Pakistan & Iran & Italy & Isle of Man & & Marshall Island \\
\hline United Arab & Kuwait & Norway & Jersey & & Montserrat \\
\hline \multirow[t]{8}{*}{ Vietnam } & Lesotho & Poland & Latvia & & $\begin{array}{l}\text { Saint Kitts and } \\
\text { Nevis }\end{array}$ \\
\hline & Lithuania & Romania & Liechtenstein & & Saint Lucia \\
\hline & Macau, & Russia & Luxembourg & & $\begin{array}{l}\text { Saint Vincent and } \\
\text { the Grenadines }\end{array}$ \\
\hline & Oman & Slovakia & Singapore & & Venezuela \\
\hline & Qatar & South Africa & South Korea & & \\
\hline & Saudi Arabia & Spain & & & \\
\hline & Taiwan & Sweden & & & \\
\hline & & $\begin{array}{l}\text { United } \\
\text { Kingdom }\end{array}$ & & & \\
\hline
\end{tabular}

Source: Regulation of Cryptocurrency Around the World, 2018, Available online at https://www.loc.gov/law/help/cryptocurrency/cryptocurrency-world-survey.pdf.

Some countries have expanded and adapted the laws on organized crime, money laundering and terrorist financing so that they can cover the issue of cryptocurrencies, so that they are able to require financial institutions and banks to meet the requirements imposed by the laws issued. In this case we find Canada and Australia who have developed and adopted laws on transactions with cryptocurrencies and institutions operating in this field, on money laundering and terrorist financing. In other countries they have completely banned any activity involving cryptocurrencies (for example: Algeria, Bolivia, Morocco), while others have restricted investments or transactions with cryptocurrencies (for example: China, Qatar). Other states have developed their own cryptocurrency system (Ireland, Venezuela, etc.). 
At the level of the European Union, we are looking for efficient ways to regulate and supervise the cryptocurrency market, protecting users and avoiding their use for illegal activities, such as money laundering, terrorist financing, etc. There have been debates regarding the transposition of cryptocurrency transactions in the AMLD4 sphere, but it cannot be annexed to the cryptographic scheme (European Parliament, 2018). Due to the scale of the phenomenon and the fact that one of the important applications of other blockchain technology in the field of finance are cryptocurrencies, this issue arose in 2018 after the publication of the Commission's Fintech 5 Action Plan (European Commission, 2020). The European Commission adopted in 2020 a digital financing package, which aims to optimize the competitiveness of Fintech technologies and ensure financial stability within the European Union. The new regulation also includes a legislative proposal on crypto-active-Markets in Crypto-assets (MiCA) in order to streamline the DLT - Distributed Ledger Technology and establish rules on virtual assets, with the role of protecting investors and users (European Commission, 2020)

The National Bank of Romania specified that the virtual currency is not a currency, and from a legal point of view it is not mandatory for it to be accepted for payment (The Romanian National Bank, 2015). Law no. 127/2011 regarding the activity of issuing electronic coins, the virtual currency does not enter in the category of electronic money (The Romanian National Bank, 2015). There may also be risks to the financial system regarding money laundering, terrorist financing due to lack of regulation. At the same time, the National Bank of Romania, through a press release, maintains its position issued in 2015, stating that virtual currencies are volatile, risky and will continue to monitor the evolution and impact it will have on financial stability (The Romanian National Bank, 2018).

\section{Methodology}

The main research question refers to the current status of the cryptocurrency and blockchain in Romania. In order to achieve this objective, the present study presents a qualitative research in which exhibits the operating mechanism of the blockchain system and cryptocurrencies, their advantages, disadvantages and the attempts of the European and national authorities to regulate the crypto market, as well as a study focused on main tech start-ups active in this sector. To this end, the authors performed a market survey based on available public sources. As the sector is still in early days, there are no comprehensive surveys available to consult, so the authors used also their personal insights into the market.

\section{Results and discussions}

In the last years, tech start-ups have exploded in Romania. Fueled by the success of UiPath (and not only) and the availability of venture financing, numerous entrepreneurs have launched businesses that use technology as a key enabler. Cryptocurrency and blockchain add an extra layer of deep-tech expertise, together with a universal language that allows global scalability.

Table 2 provides an overview of the start-ups analyzed, with the focus on solutions offered to the market. 
Table 2. Cryptocurrency and blockchain start-ups in Romania

\begin{tabular}{|c|c|c|c|}
\hline Name & Year & Description & Solution \\
\hline Morfin & 2018 & $\begin{array}{l}\text { Morfin is a platform for issuing, } \\
\text { distributing, transacting and redeeming } \\
\text { tokens with the purpose of increasing } \\
\text { engagement and loyalty of employees, } \\
\text { customers and community members. } \\
\text { Tokens can be distributed based on } \\
\text { rules similar to video games using } \\
\text { gamification (challenges, ranks, } \\
\text { leaderboards, badges) services } \\
\text { provided by the platform. Token } \\
\text { holders can redeem rewards defined by } \\
\text { the token issuer, which can be money } \\
\text { or non-monetary rewards. }\end{array}$ & $\begin{array}{l}\text { Anyone can download the application and } \\
\text { choose to issue tokens for a } \\
\text { community of people or join a community } \\
\text { that already uses a token. } \\
\text { Partners can also join communities and offer } \\
\text { discounted products and } \\
\text { services against tokens to the members of a } \\
\text { community. Tokens are } \\
\text { awarded automatically to members using } \\
\text { automated rules set up by the } \\
\text { community manager. (behavior based, } \\
\text { location based, external trigger } \\
\text { based). Member can spend the earned tokens } \\
\text { for the rewards offered } \\
\text { directly by the community manager or by the } \\
\text { partners shops connected } \\
\text { to the community. }\end{array}$ \\
\hline Modex & 2017 & $\begin{array}{l}\text { Modex made deployment of audited } \\
\text { and secure smart contracts are } \\
\text { significantly easier, faster and more } \\
\text { cost-effective, speeding up blockchain } \\
\text { adoption. Thanks to the software } \\
\text { solutions it brings to the industry, } \\
\text { Modex aims to make blockchain } \\
\text { 'invisible' and as easy-to-use as the } \\
\text { Internet, for companies and developers } \\
\text { alike. At the end of the day, people will } \\
\text { benefit from the advantages of } \\
\text { blockchain without knowing the inner } \\
\text { workings of this groundbreaking } \\
\text { technology. }\end{array}$ & $\begin{array}{l}\text { Modex BCDB is a new take on blockchain } \\
\text { technology which removes the need to invest } \\
\text { resources in blockchain training and } \\
\text { facilitates fast adoption of the technology in } \\
\text { businesses. Modex BCDB is able to } \\
\text { transform, with minimal changes, any type of } \\
\text { database into a decentralized database which } \\
\text { holds the same valuable characteristics } \\
\text { inherent to blockchain technology: } \\
\text { transparency, increased security, data } \\
\text { immutability, and integrity. For enterprises, } \\
\text { Modex BCDB translates into enhanced data } \\
\text { security, secure data sharing, streamlining of } \\
\text { operations, and maximum protection against } \\
\text { cyberattacks. }\end{array}$ \\
\hline Swazm & 2018 & $\begin{array}{l}\text { Swazm is a blockchain infrastructure } \\
\text { company. Through its IaaS } \\
\text { (infrastructure as service) offering, } \\
\text { Swazm offers to scale solutions for a } \\
\text { decentralized app allowing them to } \\
\text { serve millions of users at the same } \\
\text { time, without latency. The scalability } \\
\text { and innovation degree of the } \\
\text { infrastructure are demonstrated by the } \\
\text { possibility to process up to } 200.000 \\
\text { transactions per second, much more } \\
\text { than the competing technologies, and } \\
\text { by the efficiency of using informatics } \\
\text { resources, the Swazm ecosystem } \\
\text { representing a genuine decentralized } \\
\text { market for computing power. }\end{array}$ & $\begin{array}{l}\text { Swazm sees computing power as digital } \\
\text { currency, a resource that } \\
\text { can be redistributed and aimed towards } \\
\text { building hosting solutions for traditional web } \\
\text { apps, have access to decentralized personal } \\
\text { storage } \\
\text { space, giving you more safety for highly } \\
\text { private documents through the } \\
\text { use of cryptographic storage tech. Swazm } \\
\text { Blockchain can bring higher } \\
\text { data transfer speed for video, podcasts, video } \\
\text { surveillance, and general data streaming, in } \\
\text { areas ranging from business, science and } \\
\text { reaching the individual user. Decentralization } \\
\text { also means lower costs for developers and } \\
\text { their next big idea, making it easier, faster } \\
\text { and more sustainable to run the next code that } \\
\text { might transform the world we live in. More } \\
\text { storage space, higher processing speed, and } \\
\text { safer data privacy policies. }\end{array}$ \\
\hline
\end{tabular}

PICBE | 606 


\begin{tabular}{|c|c|c|c|}
\hline Name & Year & Description & Solution \\
\hline Stockberry & 2017 & $\begin{array}{l}\text { StockBerry was founded in } 2017 \text {, when } \\
\text { the founder wanted to get into Stock } \\
\text { Market Trading and after a lot of } \\
\text { reading and investigating, he found } \\
\text { that for regular traders there were no } \\
\text { mature tools available. Only } \\
\text { Institutional Traders had access to } \\
\text { expensive and complex tools, like } \\
\text { Bloomberg Terminal, so he decided to } \\
\text { build an affordable mobile app that } \\
\text { was just right for Retail Investors. }\end{array}$ & $\begin{array}{l}\text { StockBerry's most important feature is the AI } \\
\text { based Sentiment Indicator, it saves the time } \\
\text { spent to always check the news/social media } \\
\text { to see if people are talking good/bad about a } \\
\text { Crypto currency. Besides that, it also } \\
\text { provides financial data, technical \& } \\
\text { fundamental indicators, news, portfolio } \\
\text { management for both Stock \& Crypto and the } \\
\text { ability to set complex Alerts. }\end{array}$ \\
\hline LDV & 2017 & $\begin{array}{l}\text { LDV Exchange was launched with the } \\
\text { mission of being a bridge between } \\
\text { crypto and fiat. The keywords for LDV } \\
\text { are simplicity and speed. Simplicity for } \\
\text { easy access to crypto, even for those } \\
\text { who are at the beginning of the journey } \\
\text { and are not so familiar with } \\
\text { complicated platforms and processes. } \\
\text { And speed by optimizing the routes } \\
\text { between liquidity providers and } \\
\text { banking partners }\end{array}$ & $\begin{array}{l}\text { The platform offers both online exchanges } \\
\text { through banking, fiat to crypto, and cash } \\
\text { exchanges through the Crypto Spots network, } \\
\text { an innovative product worldwide designed as } \\
\text { a much better alternative to crypto ATMs. } \\
\text { The Crypto Spots service offers any } \\
\text { company, especially exchange offices, the } \\
\text { possibility to offer cryptocurrency sale- } \\
\text { purchase services on the same business } \\
\text { model as in collaboration with Western } \\
\text { Union. LDV delivers the technical and } \\
\text { management solution, and partners provide } \\
\text { the office space and operators. The result is } \\
\text { cash exchanges done with a human operator, } \\
\text { which is much easier and safer for those who } \\
\text { trade. }\end{array}$ \\
\hline Sablier & 2017 & $\begin{array}{l}\text { Sablier is a protocol and a suite of web } \\
\text { applications for money streaming, built } \\
\text { on the Ethereum blockchain. Launched } \\
\text { in December } 2019 \text {, it has since } \\
\text { welcomed a consistent influx of }>1,000 \\
\text { users per month and processed more } \\
\text { than } \$ 160,000 \text { worth of ERC- } 20 \text { tokens }\end{array}$ & $\begin{array}{l}\text { Sablier makes it possible for employees and } \\
\text { freelancers to get paid in real-time; instead of } \\
\text { a large chunk paid at the end of the month, } \\
\text { they receive a drip of money every second. } \\
\text { There are inherent risks when exchanging } \\
\text { labor for money - Sablier helps digital natives } \\
\text { avoid not getting paid. Some people used } \\
\text { Sablier to stream money to their kids, rate- } \\
\text { limiting their pocket money. Some } \\
\text { companies started accepting Sablier as a } \\
\text { subscription option: instead of paying upfront } \\
\text { for one month, users can start a stream that } \\
\text { they can always cancel back in case they're } \\
\text { not satisfied with the software product. } \\
\text { Finally, developers from across the world } \\
\text { started building on top by crafting new web } \\
\text { interfaces for accessing the Sablier protocol. }\end{array}$ \\
\hline Elrond & 2017 & $\begin{array}{l}\text { Elrond's vision is to (1) create a global, } \\
\text { transparent, near-instant, non- } \\
\text { inflationary financial system, and ( } 2 \text { ) } \\
\text { give anyone, anywhere, easy access to } \\
\text { it. }\end{array}$ & $\begin{array}{l}\text { To achieve the first part of the vision, Elrond } \\
\text { has built a blockchain that can process } \\
\text { transactions at the internet scale, } 1000 x \text { faster } \\
\text { and more efficient than Bitcoin or Ethereum, } \\
\text { with } 100 x \text { lower transaction cost. The Elrond } \\
\text { network has been launched in production on } \\
\text { July } 30,2020 \text {, and can process more than } \\
15.000 \text { transactions/second, with a } 6 \text { second } \\
\text { latency, and a } \$ 0.001 \text { transaction cost. For the } \\
\text { second part of the mission, Elrond build }\end{array}$ \\
\hline
\end{tabular}

PICBE | 607
DOI: 10.2478/picbe-2021-0056, pp. 601-610, ISSN 2558-9652 |

Proceedings of the $15^{\text {th }}$ International Conference on Business Excellence 2021 


\begin{tabular}{|c|c|c|c|}
\hline Name & Year & Description & Solution \\
\hline & & & $\begin{array}{l}\text { Maiar: the simplest and most powerful } \\
\text { financial application, enabling easy, global, } \\
\text { and inexpensive crypto and money transfers, } \\
\text { to anyone with a mobile phone. With Maiar, } \\
\text { Elrond aims to open the digital economy to } \\
1 \text { Billion people. By combining these two } \\
\text { components, and building a native digital } \\
\text { currency called eGold on top of them, Elrond } \\
\text { aims to radically simplify and redefine the } \\
\text { experience around crypto and money, } \\
\text { extending easy access to the digital economy, } \\
\text { to anyone in the world. }\end{array}$ \\
\hline Tailpath & 2018 & $\begin{array}{l}\text { TailPath provides secure tracking of } \\
\text { goods and provenance to physical } \\
\text { products while using blockchain } \\
\text { technologies to secure the data. Its } \\
\text { mission is to improve the supply chains } \\
\text { and have a positive impact on the } \\
\text { quality of life for people all over the } \\
\text { world. }\end{array}$ & $\begin{array}{l}\text { TailPath was used at the NATO Vigorous } \\
\text { Warrior } 2019 \text { military exercise and it is a } \\
\text { member of Blockchain in Transport Alliance, } \\
\text { working on technical standards that are used } \\
\text { across supply chain industries such as food } \\
\text { and beverages, medical and goods } \\
\text { manufacturing. TailPath is also the first } \\
\text { company to use the new Elrond blockchain } \\
\text { that is providing more than } 15.000 \\
\text { transactions per second. The Elrond main } \\
\text { network is live and TailPath takes full use of } \\
\text { its capabilities as a trusted partner. }\end{array}$ \\
\hline
\end{tabular}

The above table is not exhaustive, as it aims to provide only the most relevant examples of blockchain and cryptocurrency start-ups in Romania. Nevertheless, we can notice few characteristics even from this sample.

All the start-ups analyzed are born in Romania but look at the global market. This is possible due to the nature of their technology and necessary due to the small size of the Romanian market. Therefore, they are somehow obliged to penetrate other markets in order to become sustainable. The technology that they develop requires massive investments that will be reaped only by a global expansion.

In a deeper view into the presented start-ups, it can be noticed that, within the macro category of cryptocurrency and blockchain, there are sub-categories. Some start-ups provide payments solutions, others act as digital banks or infrastructure enablers. Figure 1 presents a taxonomy of the presented start-ups.

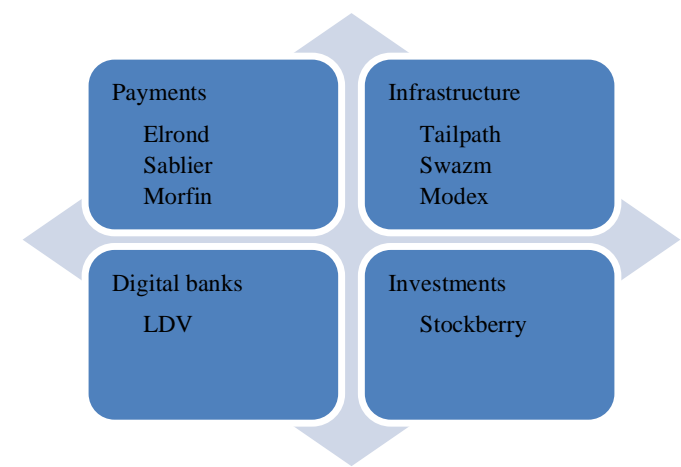

Figure 1. Taxonomy of blockchain and cryptocurrency startups in Romania

Source: authors' own research.

DOI: 10.2478/picbe-2021-0056, pp. 601-610, ISSN 2558-9652 |

Proceedings of the $15^{\text {th }}$ International Conference on Business Excellence 2021 
From the above start-ups, Elrond is the most active. At the beginning of 2021, the company announced that their virtual currency (EGLD) has reached the 1-billion-dollar valuation, thus making them an 'unicorn'. Elrond is a complete redesign of blockchain architecture with the aim to achieve global scalability and near instant transaction speed. Elrond's architecture rests on few key innovations, like adaptive state sharding and secure proof of stake. Resiliency, speed and security are also key components, especially when dealing with the cryptocurrency. For example,

Elrond network is capable of processing transactions at a speed of 1000 times higher versus other blockchain applications.

\section{Conclusion}

The entire blockchain system and cryptocurrencies represents a technological innovation, which generates both advantages and disadvantages for users, investors, entrepreneurs and regulators. Finding the optimal operating framework to reduce the risks can generate major benefits for the actors involved. The magnitude of this phenomenon causes some states to take drastic measures of prohibition, respectively restriction or, in other countries, to issue their own virtual currencies.

The blockchain and cryptocurrency sector is rapidly developing in Romania. And, in the authors' opinion, this is just the beginning and it's likely to see a much more intense development in the future.

This is due to the main characteristics and benefits that the sector is bringing. The first one is innovation, as these tech start-ups change the paradigm in many areas. As the innovation is maturing, it replaces the old technologies and challenges traditional players, like classical banks. Closely linked with innovation (and as a result of it), the second benefit is democratization. All the start-ups analyzed have this attribute in their vision and mission and really contribute towards this goal. Now, users from all over the world have secured access to blockchain transactions without any previous authorizations or even solid knowledge on finance. True, this raises some concerns, but responsible companies have always managed to mitigate these risks.

The present paper has certain limitations, first of all, due to the limited number of start-ups analyzed. The authors have tried to identify all the significant players in the market, but without the aim to have an exhaustive research. Also, there were not analyzed the foreign players that operate in Romania, although in this virtual world, there are no borders, so the concept of national market is no longer valid. This is one of the possible future directions for research, by understanding how the blockchain companies scale up their operations and work globally.

\section{References}

Bech, M., Garratt, R. (2017). Central Bank cryptocurrencies, International banking and financial market developments, BIS Quarterly Review, Bank for International Settlements, September 2017, Retrieved from https://www.bis.org/publ/qtrpdf/r_qt1709f.pdf.

Christidis, K., Devetsikiotis, M. (2016). Blockchain and Smart Contracts for the Internet of Things, The Plethora of Research in Internet of Things, (IoT), IEEE ACESS, Vol. 4, 2292-2303, Retrieved from https://ieeexplore.ieee.org/document/7467408.

Crosby, M., et al. (2016). Blockchain Technology: Beyound bitcoin, Applies Innovation, Scopus, 2(2), 6-10. 
Dwyer, G.P. (2015). The economics of Bitcoin and similar private digital currencies, Journal of Financial Stability 17, 81-91, Retrieved from https://www.sciencedirect.com/science/ article/pii/S1572308914001259?via\%3Dihub.

Edward, V.M., et al. (2015). Bitcoin: Questions, Answers and Analysis of Legal Issues, Congressional Research Service, Retrieved from https://fas.org/sgp/crs/misc/R43339.pdf.

European Commission (2020). Proposal for a Regulation of the European Parliament and of the Council on the Markets in Crypto-assets and amending Directive EU 2019/1937.

Fran, C., et al. (2018). A systematic literature review of blockchain-based applications: Current status, classifications and open issues, Telematics and Informatics, Volume 36, march 2019, 55-81, Retrieved from https://www.sciencedirect.com/science/article/pii/S0736585 318306324?via\%3Dihub.

Hossein, H., et al. (2018). Big-Crypto: Big Data, Blockchain and Cryptocurrency, Big Data and Cognitive Computing, MDPI, 2, 34, 1-15, Retrieved from.

Mourdoukoutas, P. (2018). Bitcoin, Ethereum and Litecoin are the most popular Cryptocurrency Investments Among Millennials, Retrieved fromhttps://www.forbes.com/sites/panosmour doukoutas/2018/03/25/bitcoin-ethereum-and-litecoin-are-the-most-popular-cryptocurrencyinvestments-among-millennials/?sh=63a736ac76dd.

Nakato, S. (2008). Bitcoin: A Peer-to-Peer Electronic Cash, Retrieved 12 June 2019, https:// www.ussc.gov/sites/default/files/pdf/training/annual-national-training-seminar/2018/Emer ging_Tech_Bitcoin_Crypto.pdf.

Samuel, F.W., et al. (2015). How big data can make big impact:Findings from a systematic review and a longitudinal case study, Vol. 165, July 2015, 234-246, Retrived from https://www. sciencedirect.com/science/article/abs/pii/S0925527314004253?via\%3Dihub.

Scheau, M.C., Zaharie, P.S. (2018). The way of cryptocurrency, Economy Informatics, $18(1 / 2018), 32-44$.

Scheau, M.C. (2018). Criminalitatea informatica privind transferurile financiare/ Cybercrime regarding financial transfers, Editura Economica, Bucuresti/Craiova, ISBN 978-973-709871-9, ISBN 978-606-11-6645-9.

Schroeder, S. (2017). Cryptocurrency exchange EtherDelta got replaced with a fake site that steals your money, Tech, Mashable, 21 december, Retrieved from https://mashable.com/ 2017/12/21/etherdelta-hacked/?europe=true.

Taylor, P., et al. (2020). A systematic literature review of blockchain cyber security, Digital Communications and Networks, 6(2), May 2020, 147-156, Retrieved from https://www. sciencedirect.com/science/article/pii/S2352864818301536?via\%3Dihub, Retrieved from https://www.bnr.ro/page.aspx?prid=10016.

The Law Library of Congress (2018). Regulation of Cryptocurrency Around the World, Global Legal Research Center, Retrieved from https://www.loc.gov/law/help/cryptocurrency/ cryptocurrency-world-survey.pdf.

The Romanian National Bank (2015). Press release on virtual currency scheme, Retrieved from https://www.bnr.ro/page.aspx?prid=10016.

The Romanian National Bank (2018). The positions of the Romanian National Bank in relation to virtual currencies, Retrieved from https://www.bnr.ro/page.aspx?prid=14338.

Xiaoqi, L., et al. (2020). A survey on the security of blockchain systems, Future Generation Computer Systems, Vol. 107, June 2020, 841-853, Retrieved from https://www.science direct.com/science/article/pii/S0167739X17318332?via\%3Dihub. 